\title{
Assessing basin heterogeneities for rainfall-runoff modelling of the Okavango River and its transboundary management
}

\author{
VERENA BAUMBERG ${ }^{1}$, JÖRG HELMSCHROT ${ }^{2}$, THOMAS STEUDEL ${ }^{1}$, \\ HENDRIK GÖHMANN ${ }^{1}$, CHRISTIAN FISCHER ${ }^{1} \&$ \\ WOLFGANG-ALBERT FLÜGEL ${ }^{1}$ \\ 1 Department of Geoinformatics, Geohydrology and Modelling, Friedrich-Schiller-University of Jena, Löbdergraben 32 \\ D-07737 Jena, Germany \\ verena.baumberg@uni-jena.de \\ 2 Biodiversity, Evolution and Ecology of Plants (BEE), University of Hamburg, Ohnhorststr. 18, D-22609 Hamburg \\ Germany
}

\begin{abstract}
The neighbouring river systems Cubango and Cuito drain the southeastern part of the Angolan Highlands and form the Okavango River after their confluence, thus providing 95\% of the Okavango River discharge. Although they are characterised by similar environmental conditions, runoff records indicate remarkable differences regarding the hydrological dynamics. The Cubango River is known for rapid discharges with high peaks and low baseflow whereas the Cuito runoff appears more balanced. These differences are mainly caused by heterogeneous geological conditions or terrain features. The Cubango headwaters are dominated by crystalline bedrock and steeper, v-shaped valleys while the Cuito system is characterised by wide, swampy valleys and thick sand layers, thus attenuating runoff. This study presents model exercises which have been performed to assess and quantify these effects by applying the distributive model J2000g for each sub-basin. The models provide reasonable results representing the spatio-temporal runoff pattern, although some peaks are over- or underestimated, particularly in the Cuito catchment. This is explained by the scarce information on extent and structure of storages, such as aquifers or swamps, in the Cuito system. However, the model results aid understanding of the differences of both tributaries in runoff generation and underpin the importance of floodplains regarding the control of runoff peaks and low flows in the Cuito system. Model exercises reveal that basin heterogeneity needs to be taken into account and must be parameterised appropriately for reliable modelling and assessment of the entire Okavango River basin for managing the water resources of the transboundary Okavango River in a harmonious way.
\end{abstract}

Key words basin heterogeneity; Cubango River; Cuito River; distributed hydrological modelling; flood plain morphology; HRU, hydrological system analysis; J2000g; Okavango River

\section{INTRODUCTION}

The transboundary Okavango River basin is one of the largest endorheic river basins in Africa. It is known for its unique habitats for a rich diversity of plants and animals. The Okavango River has its source in the Angolan Highlands where intense rainfalls during the rainy season generate runoff that is routed down into the Kalahari Basin where the Okavango River has formed the Okavango Delta. About $95 \%$ of the Okavango River discharge is contributed by the two major tributaries, namely the Cubango and the Cuito rivers which form the Okavango River at their confluence near the city of Dirico (Fig. 1).

Although neighbouring each other, these two river systems differ remarkably in their hydrological system behaviour (Fig. 1). Long-term runoff records of the Cubango River at station Rundu indicate seasonal discharge dynamics as well as high runoff peaks after the rainfall period, combined with low baseflow throughout the dry season. In contrast, the runoff of the Cuito River (Dirico) appears more balanced with significantly lower peaks and a generally higher baseflow. Steudel et al. (2013) have shown that the intra-annual variations in flow differ significantly, as the Cubango River discharge varies between $418 \mathrm{~m}^{3} \mathrm{~s}^{-1}$ (April) and $45 \mathrm{~m}^{3} \mathrm{~s}^{-1}$ (October) compared to the Cuito with $230 \mathrm{~m}^{3} \mathrm{~s}^{-1}$ (April) and $110 \mathrm{~m}^{3} \mathrm{~s}^{-1}$ (October).

Previous modelling efforts assessing the hydrology of the Okavango River system have either concentrated on the hydrological processes of the entire Okavango River system (Anderson et al. 2006, Hughes et al. 2006) or the hydrology of the delta (Bauer et al. 2006, Wolski et al. 2006). The majority of these studies provide information on the overall water budget and flow dynamics rather than assessing the spatial and temporal pattern of runoff generation and the impact of water retention in the upper and middle reaches. To allow for the sustainable management of the water 
resources of the Okavango River basin, the diversity of both tributaries needs to be taken into account when assessing the potential for building water supply infrastructures, hydropower plants or large scale irrigation schemes, as suggested in various water management plans.

To better understand runoff generation mechanisms and to identify major controls causing the diverse runoff generation and storage dynamics in both catchments, the influences of the geological structure, terrain, climate, soils and land cover are analysed and compared. Taking the diverse landscape features of both tributaries into consideration, two distributed hydrological models were set up to compare and assess the spatio-temporal variability of the hydrological components and runoff generation mechanisms. Both models are based on a modified version of the J2000g model (Krause et al. 2010), which has been enhanced by a module to enable modelling of capillary rise of groundwater within the capillary fringe of the unsaturated zone.

\section{MATERIAL AND METHODS}

\section{Study site}

The river systems of the Cubango and the Cuito are located in southeastern Angola between 12 and $18^{\circ} \mathrm{S}$. With an area of about $103800 \mathrm{~km}^{2}$ the Cubango catchment is almost twice as large as the Cuito system $\left(57300 \mathrm{~km}^{2}\right)$. Both catchments are of an oblong shape with a maximum extent of $750 \mathrm{~km}$ (Cubango) and $600 \mathrm{~km}$ (Cuito) from north to south. The runoff data were recorded at the gauging stations in Rundu for the Cubango River and in Dirico for the Cuito River (Fig. 1).
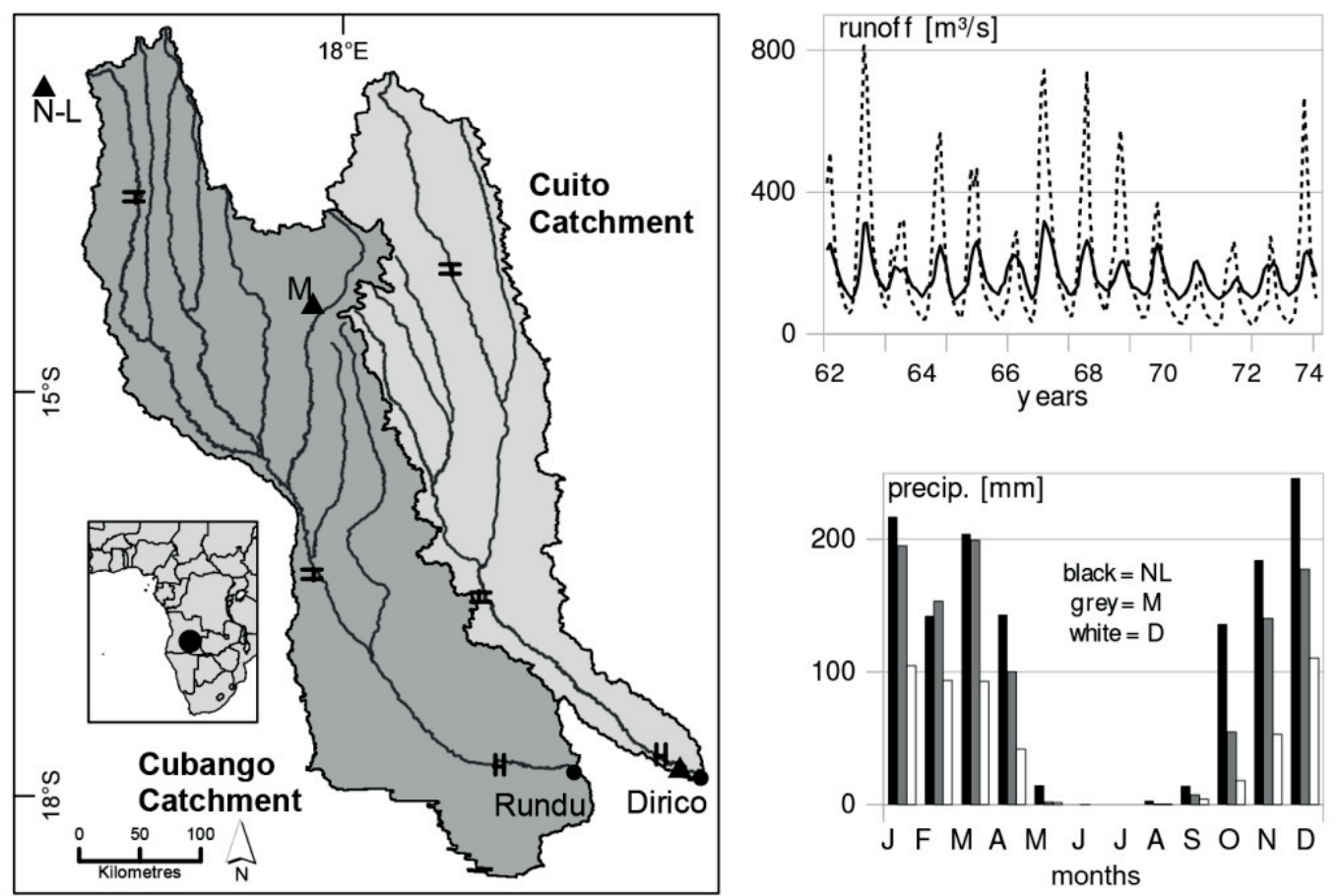

Fig. 1 Overview of the study site: observed monthly runoff for the Cubango (dotted) and the Cuito River for 1962-1975; location of the catchments and gauging stations; mean monthly precipitation (1962-1974) for Nova Lisboa (NL), Menongue (M) and Dirico (D) (triangles). Position of transverse valley profiles shown in Fig. 3 are marked on the map.

The semi-arid climate is strongly affected by the Intertropical Convergence Zone which influences the northern part of the study area by causing convective and intensive rainfall events on a daily basis between December and March (Kgathi et al. 2006). Due to the higher elevations in the Angolan Highlands, the headwaters of the Cubango system receive $900-1300 \mathrm{~mm}$ year $^{-1}$ whereas the mean annual precipitation in the Cuito headwater region varies between 700 and 1200 $\mathrm{mm}$. The southern parts of the study site are more arid with a rainfall season from December to January (Fig. 1). Temperatures remain low to moderate for tropical conditions due to the higher 
elevation on the plateau (McSweeney et al. 2010). They range from $13-17^{\circ} \mathrm{C}$ in June/July to $20-25^{\circ} \mathrm{C}$ in January (Bethune et al. 2009).

The geology is dominated by the Precambrian Congo Craton underlying both catchments (Jones 2010). Large parts of the Cuito catchment and the southern parts of the Cubango catchment are covered by sedimentary rocks of the Karoo Supergroup overlain by unconsolidated Kalahari sands (Bereslawski 1997, Catuneanu et al. 2005). Clay lenses, lime rock, unconsolidated debris and laterites can also be found (Jones 2010). In contrast, the headwater region of the Cubango River is characterised by crystalline bedrock comprising granite, dolerite or porphyrite with no or only thin layers of Kalahari sands. During the Precambrian, diagenesis formed metamorphic rocks such as gneiss, migmatite or quartzite (Bereslawski 1997).

The Cubango River has its source at about $1800 \mathrm{~m}$ a.s.l. in the Angolan Highlands. The headwaters are characterised by $\mathrm{v}$-shaped valleys incised into the crystalline bedrock. Slope varies between 5 and $20^{\circ}$, and cascades or rapids are common (Mendelsohn and el Obeid 2004). In the middle course, valleys have been filled with sediments; further downstream slope decreases and the valleys widen, so meanders and abandoned channels have developed (Bethune et al. 2009). Upstream of the confluence, the Cubango River flows through wide valleys with sandy terraces and flood plains (Kgathi et al. 2006). The Cuito River rises from the lower regions of the Angolan Highlands at $1500 \mathrm{~m}$ a.s.l., so the slope remains gentle and flow velocity is comparatively low (Mendelsohn and el Obeid 2004). Throughout the Cuito system, valley floors are 3-6 km wide and very flat. Meanders and abandoned channels are associated with extensive flood plains (Bethune $e t$ al. 2009).

Depending on the geological parent material and the influence of tropical temperatures and seasonality in rainfall, typical zonal soils have developed in the study area. The soils are generally deeply weathered and low in nutrients (Mendelsohn and el Obeid 2004). Most parts of the study area are covered with (Ferralic) Arenosols with low cation exchange capacity and low water holding capacity (Hartemink and Huting 2005). In the Cubango headwater region deep Ferralsols have formed which are also characterised by nutrient-poor quartz grains and a loose, single-grained soil texture. Small patches of Plinthosols can be located in the northern Cubango catchment. Desiccation during very dry periods leads to hardening and encrusting of these soils. Nutrient-rich Fluvisols with good water holding properties can be found along the rivers (Mendelsohn and el Obeid, 2004) in both tributaries. Mainly in the Cuito catchment, Gleyic Arenosols have developed within the river valleys; these soils are exposed to moist and therefore anaerobic conditions as a consequence of their contact with the groundwater table (Batiano et al. 2006).

The northern parts of the study site are characterised by close to open Miombo-woodlands. Depending on the water supply, these trees are either deciduous or evergreen (Campbell et al. 1996). Towards the south, the forests thin out and turn into open grasslands and woody savannah. The flood plains are overgrown with grass or reeds (Bethune et al. 2009).

\section{Model application}

Modelling exercises were carried out on a monthly basis for the period 1962-1975 with the distributed J2000g model incorporating the spatial distribution concept of Hydrological Response Units (HRU), which was developed by Flügel (1995). The J2000g model is a conceptual hydrological model with a modular structure (Krause et al. 2010) taking all essential hydrological processes into account. The model concept applies spatially distributed hydro-meteorological input datasets and simulates the distributed runoff generation for each HRU at the given time step (Krause 2002). Model calibration was automatically performed using OPTAS (Fischer 2013), followed by manual correction. The model efficiency was assessed applying the Nash-SutcliffeEfficiency (E2) and the coefficient of determination $\left(\mathrm{r}^{2}\right)$. Static landscape system parameters are represented in the HRUs, which were delineated by GIS overlay analysis applying the processrelated criteria slope, aspect, geology, soils and land use. The pixel resolution used was $270 \mathrm{~m}$. The variable input data consist of the climate data including precipitation, mean, minimum, and maximum temperature, sunshine duration, relative humidity and mean wind speed. 


\section{RESULTS}

Both models provide reasonable results for the spatio-temporal runoff pattern in each catchment for the entire period. Good fits for dry and moderate conditions are achieved for the Cubango River while high peak flows are slightly underestimated. Nash-Sutcliffe-Efficiency E2 of 0.73 and $\mathrm{r}^{2}$ of 0.73 for the Cubango system confirm the good representation of the model. The model for the Cuito River simulates the timing of runoff generation well but under- or overestimates baseflow. Peak flows are fairly underestimated during eight years and overestimated for three rainfall periods. Efficiencies for the Cuito system range from 0.37 for E2 to 0.48 for $\mathrm{r}^{2}$. Despite some discrepancies in the simulated hydrographs, both models provide a water balance that is in agreement to the results published by Mendelsohn and el Obeid (2001).

Regarding the spatio-temporal distribution of the hydrological components, the model simulates decreasing precipitation, total runoff generation and groundwater recharge from north to south throughout the rainy season (e.g. in March). The amount of precipitation declines from over $200 \mathrm{~mm}$ in the north to less than $120 \mathrm{~mm}$ in the south (compare Fig. 2). Similarly the groundwater recharge also decreases from about $170 \mathrm{~mm}$ to less than $100 \mathrm{~mm}$. The soil moisture also reflects this tendency, but shows lower values of approx. 50\% in the Miombo woodland areas of the middle reaches of both tributaries. In the headwater region of both river systems the soils are saturated, whereas soils in the southern parts show a saturation of approx. 30\%. The model simulates high rates of actual evapotranspiration $(160 \mathrm{~mm})$ in the central vegetated areas and lower rates of $70-100 \mathrm{~mm}$ in the cooler Highlands as well as in the dry southern parts during the rainfall period.

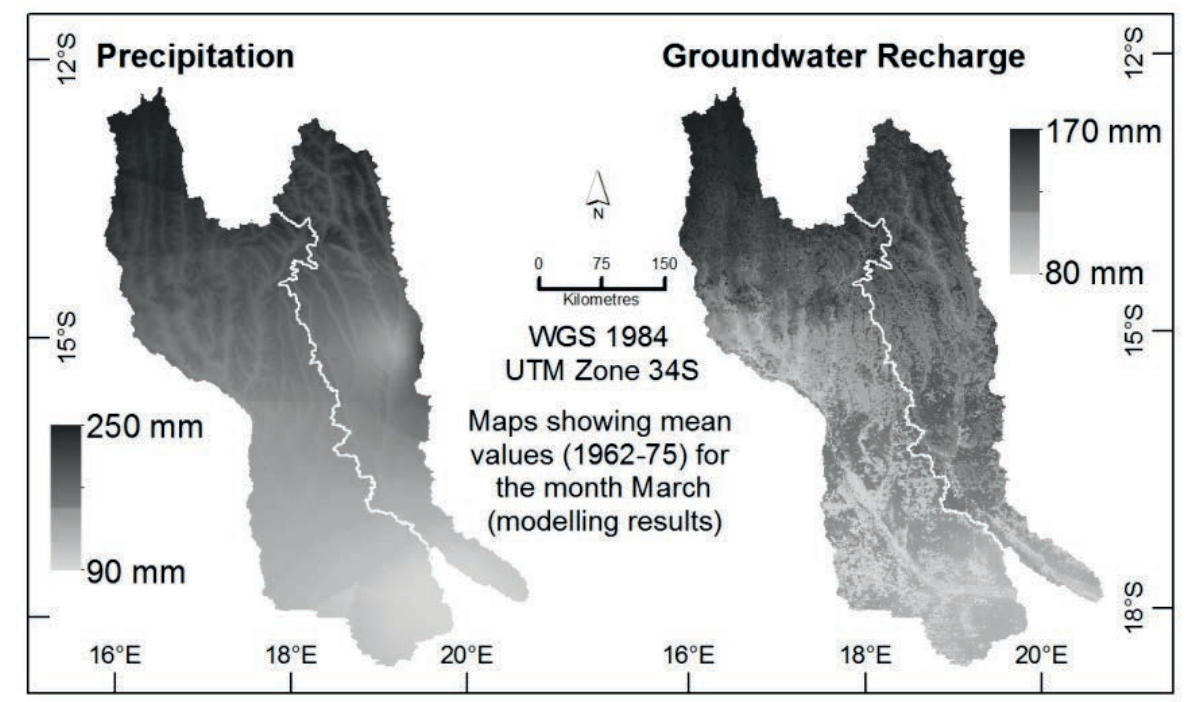

Fig. 2 Modelling results: mean values for precipitation and groundwater recharge for March (mean 1962-1975).

\section{DISCUSSION}

Both models simulate the intra-annual distribution of hydrological components controlled by the seasonality of rainfall and complemented by different landscape properties. Hence, calibration is essential for the modelling results as hydrological processes and the properties of the respective systems cannot be entirely reproduced by only the conceptual model structure. Parameter calibration is indispensable for realistic results and not transferable to the other catchment.

As stated earlier, gradients in rainfall, temperature or evapotranspiration, as well as land cover and soils, are distributed evenly across the study site. Therefore these factors do not per se cause the different hydrological behaviour in the two catchments. The assembly of geological and geomorphological landscape features triggers their different hydrological responses. With increasing elevation towards the Angolan Highlands in the northern parts, the amount of precipitation increases, so there is a clear relationship between topography and climate influencing runoff generation. As a 
result, the majority of the runoff is generated in these headwater regions of both tributaries, as represented by the model results and stated by Mendelsohn and el Obeid (2004).

The underlying geological structures of the Cubango headwaters consist of hard crystalline rock material (Jones 2010) and as shown in Fig. 3, the Cubango River runs through narrow valleys of often less than $1 \mathrm{~km}$ in width compared to the Cuito system $(3 \mathrm{~km})$ (Bethune et al. 2009). Combined with a steep slope, this leads to a higher percentage of direct runoff generated from rainfall events and increased flow velocity. The igneous and metamorphic rocks show poor water holding properties, so groundwater storage is very low (Jones 2010, MacDonald et al. 2012). The Cuito River headwater region is characterised by thick Kalahari sand layers. Due to their high porosity, rainwater infiltrates quickly and surface runoff rarely occurs (Jones 2010). The sedimentary aquifer stores large quantities of groundwater and functions as a groundwater reservoir (MacDonald et al. 2012). Throughout rainfall periods, the water percolates into the sedimentary aquifer. The discharge towards the rivers is delayed during the dry season, especially in the south (Mendelsohn and el Obeid 2001).

A further distinction of the Cubango headwaters is due to the morphology of river valleys. The Cuito valleys are wide and only slightly sloped. Oxbow lakes, swamps and flood plains are present adjacent to the meandering river courses (Bethune et al. 2009). The swamps and flood plains form natural retention areas retaining large volumes of water, buffering runoff peaks during the rainy season and supporting baseflow during the dry season.
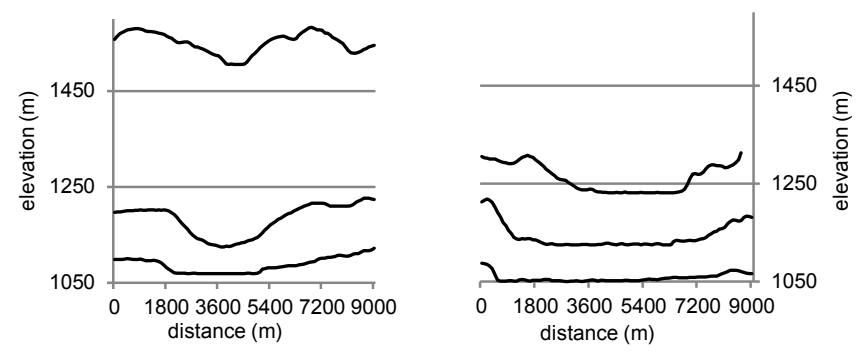

Fig. 3 Transverse valley profiles of the Cubango (left) and Cuito (right) for the headwaters (top), middle course (centre) and lower course (bottom) of both rivers. Pixel resolution of DEM: $90 \mathrm{~m}$. Location, see Fig. 1.

This hypothesis is supported by findings of a terrain analysis applied to a digital elevation model (DEM $90 \mathrm{~m}$ ). In this analysis, a buffer zone of $2.7 \mathrm{~km}$ on each side of the rivers was extracted. Within this riparian zone, all areas with a slope of less than $0.8^{\circ}$ were identified and classified as potential flood plains. In the Cubango catchment, the area of flood plains is quantified as 9.04 ha per $\mathrm{km}^{2}$ of riparian zone. In contrast, $20.43 \mathrm{ha}$ per $\mathrm{km}^{2}$ of riparian zone are classified as flood plains in the Cuito system. These differences become more significant in the headwater regions, where most of the runoff is generated. Furthermore, a spatial analysis of the Topographic Wetness Index (Beven and Kirkby 1979) also shows larger areas for potential wetlands or water retention in the Cuito riparian zone (7.8\% of the riparian zone area) than in the Cubango riparian zone $(4.8 \%)$. So not only the geological structure and the soil distribution, but also topographic properties impact the hydrological system dynamics of the two river systems by means of enlarging the runoff buffering and storage within the Cuito catchment.

In conclusion, the model results and the hydrological system analyses show the importance of the landscape heterogeneity of the two tributaries of the Okavango River. While the larger catchment size in combination with higher precipitation in the Angolan Highlands generates faster runoff responses and higher runoff volumes in the Cubango catchment, the differences in baseflow dynamics are caused by different groundwater aquifer dynamics and topographic landscape features, especially in the valleys and flood plains of each catchment. 


\section{OUTLOOK}

For good model performance, the effects of bank storage in the riparian zones and the attenuation of runoff peaks caused by swampy valleys and thick layers of Kalahari sands in the Cuito catchment must be considered and included in the model concept. Consequently basin heterogeneity must be represented in sufficient degree in the model for reliable modelling of the entire Okavango River basin. To achieve better results for the Cuito River, detailed information concerning the extent and structure of internal surface and subsurface water storages are required. The HRU delineation needs to focus more on riparian zones to represent the delaying impact of the meandering river drainage network and the storage function of the riparian wetlands. Although these areas are only small relative to the entire catchment, they control to a significant degree the hydrological processes in the Cuito catchment.

Acknowledgements This study is part of the project "The Future Okavango", funded by the German Ministry for Education and Research (BMBF). The authors would like to thank the Department of Geoinformatics, Geohydrology and Modelling, Friedrich-Schiller-University, the Angolan Meteorological Service and the Angolan National Water Resource Institute (NWRI) for providing logistic support in the field campaigns and providing data for the modelling exercises.

\section{REFERENCES}

Anderson, L., et al. (2006) Impact of climate change and development scenarios on flow patterns in the Okavango River. $J$. Hydrol. 311, 43-57.

Batiano, A., et al. (2006) African Soils: Their Productivity and Profitability of Fertilizer Use. African Fertilizer Summit. Background Papers 1-25.

Bauer, P., Gumbricht, T., and Kinzelbach, W. (2006) A regional coupled surface water/groundwater model of the Okavango Delta, Botswana. Water Resour. Res. 42(4), W04403/1-W04403/15.

Bethune, S., Mazvimavi, D., and Quintino, M. (2009) Okavango River Basin Environmental Flow Assessment Delineation Report. OKACOM Okavango River Basin Transboundary Diagnostical Analysis Technical Report 04-2009.

Bereslawski, E. (1997) Geohydrology, Geology, and Soils of the Cubango River Basin (Angolan Sector). OKACOM Okavango River Basin Preparatory Assessment Study, Spesialist's Report.

Beven, K. J. and Kirkby, M. J. (1979) A physically based, variable contributing area model of basin hydrology. Hydrol. Sci. Bull., 24(1), 43-69.

Campbell, B., Frost, P., and Byron, N. (1996) Miombo-Woodlands and their use: an overview and key issues. In: The Miombo in Transition: Woodlands and Welfare in Africa (ed. by B. Campbell), 1-10. CIFOR.

Catuneanu, O., et al. (2005) The Karoo basins of south-central Africa. J. Afric. Sci. 43, 211-253.

Fischer, C. (2013) Automatische Kalibrierung hydrologischer Modelle. Entwicklung und Anwendung des Kalibrierungssystems OPTAS. Dissertation, Friedrich-Schiller-University of Jena, Germany.

Flügel, W.-A. (1995) Delineating hydrological response units by geographical information system analyses for regional hydrological modelling using PRMS/MMS in the drainage basin of the River Bröl, Germany. Hydrol. Processes. 3-4, 423-436.

Hartemink, A .E. and Huting, J. (2005) Sandy soils in Southern and Eastern Africa: Extent, properties and management. FAO Corporate Document Repository. Available From: <http://www.fao.org/docrep/010/ag125e/AG125E08.htm\#8.1> (201308-27).

Hughes, D. A., et al. (2006) Regional calibration of the Pitman model for the Okavango River. J. Hydrol. 311, $30-42$.

Jones, M. J. (2010) The Groundwater Hydrology of the Okavango Basin. OKACOM Okavango River Basin Transboundary Diagnostical Analysis Technical Report.

Kgathi, D. L., et al. (2006) The Okavango; a river supporting its people, environment and economic development. J. Hydrol. $331,3-17$.

Krause, P. (2002) Quantifying the impact of land use changes on the water balance of large catchments using the J2000 model. Physics and Chemistry of the Earth. 27(9-10), 663-673.

Krause, P., et al. (2010) Hydrological system analysis and modelling of the Nam Co basin in Tibet. Advances in Geosciences 27, 29-36.

MacDonald, A. M., et al. (2012) Quantitative maps of groundwater resources in Africa. Environmental Research Letters, 7, 1-7.

McSweeney, C., New, M. and Lizcano, G. (2012) UNDP Climate Change Country Profiles. Angola. School of Geography and the Environment. Available From: $<$ http://www.geog.ox.ac.uk/research/climate/projects/undp-cp/UNDP_reports/Angola/Angola.lowres.report.pdf> (2013-08-30).

Mendelsohn, J. and el Obeid, S. (2001) A preliminary profile of the Kavango Region in Namibia. Environmental Information Service Namibia. Available From: <http://www.the-eis.com/data/literature_OK/Mendelsohn4.pdf> (2013-08-30).

Mendelsohn, J. and el Obeid, S. (2004) Okavango River. The flow of a lifeline. Struik.

Steudel. T.. et al. (2013) Hvdrological assessment of hydrological dvnamics in the upper Okavango. Biodiversitv \& Ecologv 5. 247-261. doi:10.7809/b-e.00279. In: Environmental Assessments in the Okavango Region (ed. by J. Oldeland, C. Erb, M. Finckh \& N. Jürgens) ISSN 1613-9801, doi:10.7809/b-e.vol_05.).

Wolski, P., et al. (2006) Modelling of the flooding in the Okavango Delta, Botswana, using a hybrid reservoir-GIS model. J. Hydrol.,331, 58-72. 